\title{
SPIRITUALITAS BERJUANG MENJADI MISKIN DAN BERJUANG BAGI KAUM MISKIN
}

\author{
Suatu Upaya Membangun Hidup Menggereja dalam Konteks Kemiskinan dan Ketidakadilan \\ Spirituality Strive To be Poor and Strive for The Poor Efforts to \\ Build a Life of be In Church in The Context The Poverty and Inequality
}

\author{
Oleh: Salmon Pamantung* \\ *Dosen dan Pgs. Ketua STAKN Toraja \\ Alamat Kantor: Jl. Mengkendek, Makale Tana Toraja \\ Email: spamantung(S \}vahoo.com
}

\begin{abstract}
Poverty and injustice are the face of Mammon that church has to against for. Both are shown in economics structure, social matter and religios legitimation that tear and scattering the humanity: Jesus ministry was against to mammon, include to the poverty and injustiice. By struggling to become impecunious and struggle forpauper, Jesus unload the poverty and injustice, pass the crucify event in Kalvari. Church as believers community and followers of Jesus have to inspire the spirituality of Jesus in theology and praxis through advocating and stand up for the oppressed and impecunious people. The " struggling to become impecunious and struggle for pauper Sprituality, Jesus unload the poverty and the injustice, pass the event crucify in Calvari. Church as community believe and follower of Jesus have to menginiernalisasi spirituality of Jesus in theology and praxis advocating to feel and stand up for the oppressed and impecunious people.
\end{abstract}

\section{PENDAHULUAN}

$\mathrm{P}$ ara ahli memperkirakan bahwa jumlah penduduk miskin mengalami peningkatan yang cukup signiflkan, ketika krisis ekonomi tahun 1997 dan krisis global akliir tahun 2008 menimpa bangsa-bangsa di dunia, termasuk Indonesia. Berbagai media massa, baik cetak maupun elektronik menyebutkan bahwa pertumbuhan ekonomi memang mengalami pertumbuhan sekitar $3-4 \%$ pertahun, tetapi tingkat keminskinan terus mengalami peningkatan.

Setiap hari banyak orang yang hams kehilangan pekerjaan karena perusahaan atau tempat mereka bekerja mengalami kebangkrutan, sehingga menambah angka pengangguran. Pemutusan Hubungan Kerja (PHK) dari pihak perusahaan seringkali tidak memperhatikan aspek keadilan. Pemberian uang pesangon kepada para pekerja/buruh dianggap tidak dapat memenuhi kebutuhan sehari-hari. Kalaupun para pekerja mendapat uang pesangon, uang tersebut hanya untuk bertahan hidup beberapa bulan saja. Hidup di bawah garis kemiskinan mengnadung konsekwensi penderitaan, sebab orang yang hidup dalam kemiskinan sangat rentan terhadap tindak kekerasan dan perlakukan tidak adil. Fenomena kemiskinanjuga memneri dampak pada bidang kehidupan/sosial yang lain. Kasuskasus kriminalitas mengalami peningkatan pula. Kasus pencurian, penipuan, perampokan dan pembunuhan dilatarbelakangi oleh karena faktor kemiskinan (ekonomi).

Tulisan ini akan membahas bagaimanakah gereja menghadapi realitas kemiskinan, penderitaan dan ketidakadilan di Indonesia? Atau dengan kata lain, bagaimana gereja berteologi dalam konteks kemiskinan, penderitaan dan ketidakadilan di Indonesias? Gereja di Indonesia diharapkan dapat memberikan sumbangan yang bermakna dalam menangani masalah kemiskinan, penderitaan dan ketidakadilan, sehingga nilai-nilai kehidupan, kasih dan Kerajaan Allah tidak sekedar menjadi sebuah Utopia.

Untuk memudahkan memahami maksud pembahasan tulisan ini, maka penulis membuat sistematika tulisan ini sebagai berikut: 1. Pendahuluan; II. Realitas Kemiskinan dan Ketidakadilan; III. Analisis terhadap Akar Masalah Kemiskinan dan Ketidakailan; IV. 
Upaya Hidup Menggereja dalam Konteks Kemiskinan dan Ketidakadilan; V. Penutup.

\section{Realitas Kemiskinan dan Ketidakadilan}

Aloysius Pieris, seorang teolog dari Srilanka, seperti yang dikutip oleh A. A. Yewangoe, mengatakan bahwa konteks Asia dapat digambarkan dengan dua realitas, yakni: (1)rehgiositasyangmajemuk, (2)realitas kemiskinan.' Menjadi suatu fakta bahwa meskipun kemiskinan dapat ditemukan di semua tempat di dunia ini, termasuk di Negara-negara industri yang telah mengalami kemajuan di bidang ekonomi, tetapi realitas yang terdapat di "dunia ketiga" (Asia, Afrika dan Amerika Latin) jauh lebih mencolok. ${ }^{2}$ Benua Asia dikenal sebagai tempat lahirnya berbagai agama besar seperti Yahudi, Kristen, Islam, Budha, Hindu, Konghucu, Tao.

Secara sosial-ekonomi, Negara-negara di Asia (termasuk Indonesia) digolongkan sebagai negara miskin. Menurut Myrdall, yang dikutip pendapatnya oleh Yewangoe, menyatakan bahwa ap yang terkuak di Asia sesungguhnya adalah drama, sikap dan lembaga, kenyataan ekonomi dan kecenderungankecenderungan demografi, kemiskinan dan perjuangan untuk memecahkannya bertentangan dengan tujuantujuan yang diungkapkan dalam rencana modernisasi dan pembangunan. ${ }^{3}$ Dalam studinya mengenai kemiskinan, Myrdall terutama melihat kemiskinan dari sudut pandang ekonomi. Studinya tentang masalah kemiskinan ini sangat menolong kita mengakui bahwa kemiskinan adalah masalah yang besar bagi bangsabangsa di Asia.

Khusus di Indonesia, data mengenai jumlah orang miskin tidak dapat dipastikan, karena hanya merupakan perkiraan saja dari pemerintah. Pada masa Orde Baru, pemerintah mencoba melakukan pendataan jumlah orang miskin di Indonesia. Namun angkaangka yang diberikan oleh Biro Pusat Statistik sering tidak sesauai dengan kenyataan yang sesungguhnya. Jumlah orang miskin di Indonesia berdasarkan hasil pendataan pada tahun 1990 adalah sekitar 28,5 juta orang (atau 15,82\% dari jumlah penduduk Indonesia), pada tahun 1993 jumlah orang miskin menurun menjadi 25,9 juta orang (13,6\%) dan pada tahun 1998 (ketika krisis ekonomi melanda Indonesia) jumlah orang miskin mengalami peningkatan menjadi sekitar 49,5 juta orang. ${ }^{4}$ Kesulitan dalam mendata jumlah miskin di Indonesia, disebabkan oleh beberapa faktor, antara lain:

(1) Faktor psikologis. Banyak orang yang secara real hidup dalam kemiskinan secara ekonomi, namun tidak mau (tepatnya "malu") untuk disebut sebagai orang miskin. Pada era reformasi hal ini menjadi ironi, sebab ketika dilakukan pendataan jumlah orang miskin, banyak orang yang merasa "tidak terima" digolongkan sebagai orang miskin sekalipun secara ekonomis kehidupan mereka sungguh-sungguh memprihatinkan. Hal ini sangat bertentangan, ketika pemerintah menggulirkan program Bantuan LangsungTunai (BLT), orangorang beramai-ramai, tanpa rasa malu lagi menyatakan dirinya sebagai orang miskin, walaupun secara ekonomi kehidupan mereka banyak yang cukup dan mampu.

(2) Faktor politis. Pembangunan adalah salah satu program yang dicanangkan oleh pemerintah untuk mengatasi kemiskinan. Apabila jumlah angka kemiskinan meningkat, maka program pemerintah di bidang pembangunan dianggap gagal. Karena itu data yang dilaporkan bisa saja bertentangan dengan kenyataan yang sesungguhnya.

(3) Faktor kriteria yang digunakan untuk menilai seseorang dapat digolongkan sebagai orang miskin. Sejak tahun 1976, Biro Pusat Statistik menghitung angka kemiskinan berdasarkan batas kecukupan pangan dan non-pangan. Batas kecukupan pangan adalah 2100 kalori perhari/ perorang; sementara batas kecukupan nonpangan didasarkan pada sejumlah komoditi yang selayaknya dipakai oleh penduduk. Dengan dasar tersebut, pada tahun 1993, batas jumlah rupiah minimum untuk garis kemiskinan di Indonesia adalah Rp. 27,905 (untuk perkotaan) dan Rp. 18, 244 (untuk pedesaan (Harian Kedaulatan Rakyat. 1996: 7). Tahun 2008, orang yang berpenghasilan dibawah Rp. 150 ribu perbulan, dapat digolongkan sebagai orang miskin.

A. A. Yewangoe. 1996 Theologia Cruris di Asia: Pandangan-Pandangan Orang Kristen Asia mengenai Penderitaan dalam Kemiskinan dan Keberagamaan di Asia. Jakarta: BPK Gunung Mulia, h. 1.

Ibid.

Ibid.

Merphin Panjaitan. 2000. Memberdayakan Kaum Miskin. Jakarta: BPK Gunung Mulia, h. 2 
Sehubungan dengan masalah kemiskinan ada beberapa pertanyaan yang dapat diajukan, antara lain: apa penyebab dan sumber kemiskinan itu? Apakah kemiskinan yang dialami seseorang disebabkan oleh diri mereka sendiri, ataukah pengaruh struktur yang berada di luar diri mereka?

Kemiskinan menurut Malcolm Brownlee, memiliki dua dimensi, yaitu: kemiskinan material dan kemiskinan jiwa. ${ }^{5}$ Kemiskinan material terjadi karena kekurangan uang dan harta benda. Dalam kamus Besar bahasa Indonesia mendefenisikan miskin berarti tidak berharta benda, berpenghasilan rendah. Jadi yang dimaksud orang miskin adalah mereka yang tidak menguasai sarana-sarana fisik secukupnya untuk memenuhi kebutuhan dasarnya/untuk mencapai tingkat minimum kehidupan yang dapat dinilai secara manusiawi. Karena itu, orang yang miskin material kurang dalam sandang-pangan, kurang gizi, sering kurang memiliki pendidikan dan keterampilan. Kemiskinan material ini biasanya disertai pula kemiskinan jiwa. Orang-orang miskin seringkali mempunyai rasa rendah diri (inferiority) karena dianggap lebih rendah oleh orang-orang yang lebih kaya. Orang miskin merasa tidak berdaya dan cenderung bersikap masa bodoh, karena menganggap diri tidak mampu mengubah situasi kemiskinan yang dialami. Terlebih situasi kemiskinan itu diterima sebagai nasib. Tetapi tidak dapat dipungkiri penderitaan dan kemiskinan juga terjadi karena faktor manusia, strukturstruktur sosial yang menindas, Negara-negara kaya yang mengeksploitasi negera lain serta sistem internasional yang tidak adil. E. G. Singgih, dalam bukunya, Berteologi dalam Konteks menyebutkan bahwa kemiskinan terjadi bukan karena dari "sononya" atau karena kelalaian angsa Asia-Pasifik, tetapi oleh karena kekuatan ekonomi dipusatkan di belahan bumi utara (Eropa dan Amerika). ${ }^{6}$ Jika bangsa-bangsa di Asia berbicara tentang kemiskinan, hal itu merujuk pada situasi di mana orang menemukan mereka dalam struktur sosial yang menindas, sehingga mereka tidak mempunyai kesempatan untuk mengembangkan diri.

Aloysius Pieris seperti dikutip oleh Singgih, membedakan kemiskinan ke dalam dua kategori, yakni "kemiskinan sukarela" dan "kemiskinan yang dipaksakan".' Kemiskinan sukarela dapat dilihat terutama dalam kehidupan para biarawaa Kemiskinan sukarela tidak dipandang sebagai penderitaan, melainkan sebagai kebijakan. Sedangkan kemiskinan yang dipaksakan melahirkan penderitaan dan merupakan buah dosa. Dalam kemiskinan yang dipkasakan, kemiskinan dialami sebagai penderitaan yang sebenarnya. Orang-orang yang hidup dalam kemiskinan seperti ini merupakan sesuatuyang buruk, dan karena itu kemiskinan perlu diubah. Orang-orang miskin yang disebabkan kemiskinan yang dipaksakan, bereaksi terhadap situasi buruk ini dengan mencoba menemukan alternatif-alternatif untuk keluar dari situasi kemiskinan, misalnya dengan melakukan protes terhadap "kelas yang berkuasa" yang menjadi penyebab pederitaan yang mereka alami. Masalah kemiskinan tidak dapat dipisahkan dari masalah keadilan. Fernando Nimelka, yang dikutip oleh Yewangoe, menyebut ada tiga faktor penyebab kemiskinan "yang dipaksakan", yakni: ketidakadilan structural, penindasan dari sistem kapitalis dan perampokan secara sistematis oleh negara-negara kaya atas negara-negara dunia ketiga. ${ }^{8}$

Ketidakadilan gender merupakan "buah" dari kemiskinan dan penderitaan. Kira-kira dua puluh tahun yang lalu, kaum perempuan bangkit dengan gerakangerakannya yang melancarkan protes karena mengalami penindasan. Untuk memahami penindasan yang dialami oleh kaum perempuan, maka narasinarasi tentang kehidupan dan penindasan mereka menjadi referensi utama.

Kisah penindasan yang dialami oleh perempuan sudah dimulai ketika masih dalam kandungan. Dalam kebiasan yang berlaku sebagian besar di wilayah Asia, ketika anak masih dalam kandungan, anak yang diharapkan oleh keluarga adalah anak laki-laki. Testes kesehatan modern dimaksudkan untuk mengenali jenis kelamin janin. Apabila janin tersebut berjenis kelamin perempuan, akan digugurkan. Beberapa kasus bayi perempuan yang lahir, keberadaannya di tengahtengah keluarga dianggap sebagai beban. Bahkan dalam masyarakat yang sangat kuat menganut nilai patriakal, seorang anak gadis akan selalu diisolasi. Perempuan dipandang sebagai orang yang lemah, memiliki kebebasan yang terbatas, pasif, harus tunduk, bergantung dan emosional.

Malcolm Brownlee. 1997. Tugas manusia dalam Dunia Milik Tuhan. Jakarta: BPK Guming Mulia, h. 80.

E. G. Singgih. 2000. Berteologi dalam Konteks: Pemikiran-Pemikiran mengenai Kontektualisasi di Indonesia. Yogyakarta-Jakarta: Kanisius-BPK Gunung Mulia, h. 203.

Ibid, h. 19

Yewangoe, op.cit., h. 13 
Dalam lingkup tatanan sosial patriakal, perempuan tidak mempunyai kekuasaan untuk membuat keputusan. Derajat dan haknya tidak sama dengan laki-laki. Tugas utama perempuan adalah menghasilkan ahli waris atau pekerja laki-laki. Perempuan menjadi sasaran segala macam tindak kekerasan, baik jasmani maupun psikologis. Dalam bidang keagamaan, perempuan seringkali dipandang tidak suci \{unclean, karena menstruasi). Peran dan wewenangnya tidak dominan.

Di atas telah disebutkan tentang kemiskinan dan beberapa aspek yang terkait dengan masalah kemiskinan itu sendiri. Kemiskinan yang membawa penderitaan adalah kemiskinan yang disebabkan oleh sstem dan perlakukan ekonomi yang tidak adil dan menindas." Ulrich Duchrow mengatakan bahwa ketidakadilan struktur ekonomi disebabkan oleh kapitalisme ekonomi pasar global. ${ }^{10}$ Lanjut Duchrow menyebutkan bahwa penyakit-penyakit sosial sekrang ini yang terjadi di berbagai belahan dunia seperti kemiskinan, penganggran dan sebagainya adalah akibat dari pasar kapitalis global. Sistem ini disponsori oleh World Bank, IMF, Asian Development Bank, yang mana lembaga-lembaga ini adalah perpanjangan tangan dari negara-negara kaya untuk mengeskploitasi negaranegara miskin. Sistem ini sangat berpotensi untuk mendorong secara tidak terkendali kegiatan ekonomi yang mengarah pada kegiatan ekonomi penimbunan modal (bagi para pemilik modal/uang). Dengan semangat persaingan yang mutlak dalam pasar global, alam dan manusia disubordinasikan pada tujuan penumpukan modal semaksimal mungkin. Akibatnya adalah di satu pihak pendapatan global akan menumpuk bagi kelompok kapitalis yangjumlahnya sangat sedikit darijumlah populasi penduduk dunia. Sementara pada saat yang sama terjadi proses kemiskinan dalam skala besar dari jumlah sisa populasi dunia. Keadaan ini semakin diperparah oleh adanya sifat ketergantungan negara-negara miskin atas negara-negara kaya. Ketergantungan tersebut terutama pada pemberian hutang (berkedok "bantuan") bagi negara-negara miskin utuk menghidupi dan membangun perekonomian mereka. Tanpa disadari, pemberian "bantuan" ini sesungguhnya tidak membantu pembangunan perekonomian negara-negara miskin; sebaliknya yang terjadi adalah proses pemiskinan negara-negara miskin. Maka semakin lebar pulalah jurang antara negara miskin dan negara kaya.

Sistem kapitalis juga telah merambah Indonesia. Ekonomi Indonesia sangat tergantung pada "bantuan" luar negeri. Beban hutang luar negeri tidak mampu terbayarkan dengan pendapatan nasional. Perilaku korupsi yang dilakukan oleh pejabat publik dan para pengusaha nakal semakin memperparah kemiskinan di Indonesia. Skenario kriminalisasi Komisi Pemberantasan Korupsi (KPK) yang berujung pada penahanan dua pimpinan KPK Bibit S. Riyanto dan Chandra Hamzah pada akhir bulan Oktober 2009, mengindikasikan betapa budaya korupsi telah menjadi "sel cancer" yang menyerang seluruh sendi bangsa Indonesia. Sistem perekonomian yang tidak adil adalah bentuk keserakahan, kelobaan yang menghasilkan pemerasan, penindasan dan penghisapan manusia oleh manusia sendiri."

\section{PEMBAHASAN}

\section{Analisis terhadap Masalah Kemiskinan dan Ketidakadilan}

Penganut ideologi konservatif menyatakan bahwa orang miskin adalah orang yang bodoh, malas, tidak terampil dan tidak punya motivasi untuk berprestasi. Kemiskinan disebabkan oleh karena kesalahan orang miskin. Sementara penganut ideologi liberal melihat persoalan kemiskinan secara lebis serius. Para penganut ideoolgi liberal mengatakan bahwa orang menjadi miskin oleh karena tidak adanya kesempatan bagi orang miskin untuk berusaha secara maksimal. ${ }^{12}$ Baik ideologi konservatif maupun ideologi liberal sama-sama memandang kesalahan tetap terletak pada orang miskin itu sendiri yang gagal bersaing dalam pasar bebas. Pandangan kedua ideologi tidak dapat diterima begitu saja, sebab terdapat faktor eksternal yang memengaruhi sehingga orang menjadi miskin. Frans Magnis Suseno mengatakan bahwa kemiskinan dapat saja disebabkan oleh strukturisasi proses-proses ekonomi, politik, sosial-budaya dan ideologi - ketidakadilan struktural. ${ }^{13}$ Orang yang mengalami kemiskinan struktural adalah

\footnotetext{
J. B. Banawiratma. 1994. Kemiskinan dan Pembebasan. Yogyakarta: Kanisius.

${ }^{10}$ Ulrich Duchrow. 1997. Mengubah Kapitalisme Dunia. Jakarta: BPK Gunung Mulia, h. 11

S. A. E. Nababan. 1996. Iman dan Kemiskinan. Djakarta: BPK GM, h. 19

J. B. Banawiratma. op.cit, h. 16-17

${ }^{13}$ Ibid., 38 .
} 
mereka yang menjadi korban, secara psikologis maupun sosiologis terus menerus ditekan oleh struktur masyarakat yang tidak adil.

Terciptanya struktur sosial yang menindas ini dapat ditelusuri dari sejarah, yakni warisan kolonialisme. Umumnya bangsa-bangsa di Asia (termasuk Indonesia) adalah bangsa yang pernah berada dibawah impelialisme bangsa-bangsa Eropa. ${ }^{14}$ Salah satu tujuan ekspansi dan penjajahan dlah mencari dan menaklukkan daerah-daerah yang memiliki kekayaan alam, karena di negeri asal tidak tersedia sumber-sumber alam yang dibutuhkan. Daerah jajahan diperas kekayaan alamnya (ekonomi) demi keuntungan dan kesejahteraan kaum penjajah. Rakyat daerah jajahan dibiarkan hidup tanpa perhatian dalam kemiskinan.

Budaya paternal-feodalistik turut memberi kontribusi menguatnya struktur sosial yang tidak adil. Budaya paternal-feodalistik masih sangat kental dalam masyarakat suku-suku bangsa di Indonesia. Secara sosial-budaya, di kalangan suku bangsa Indonesia berlaku stratafikasi sosial. Umumnya pembagian strata itu, yakni strata sosial "tinggi" (kaum bangsawan) dan strata sosial "rendah" (kaum abdi). Kaum bangsawan seringkali dianggap sebagai keturunan "dewa" dan karenanya rakyat biasa harus tunduk kepada mereka. Para bangsawan adalah golongan yang berhak untuk memiliki harta benda, sementara rakyat biasa atau para hamba harus menerima keadaan yang serba terbatas, termasuk dalam kepemilikan harta. Bahkan tidak jarang bahwa para hamba disejajarkan dengan benda yang menjadi milik para golongan bangsawan.

Dalam analisis sosial ini, juga memperlihatkan adanya ideologi yang memandang secara ekstrim perbedaan antara laki-laki dan perempuan. Laki-laki dilihat sebagai pekerja yang dapat meningkatkan kualitas ekonomi keluarga, sedangkan perempuan dianggap sebagai mahkluk lemah yang tergantung sepenuhnya pada laki-laki. Dalam budaya yang demikian, perempuan ditempatkan pad posisi kelas dua dalam struktur masyarakat. Perempuan menjadi kelompok yang termarjinalisasi, menderita dan miskin dalam masyarakat.

Sebagaimana telah dipaparkan sebelumnya bahwa sistem perekonomian dengan gaya kapitalisme adalah salah satu penyebab terjadinya kemiskinan. Negaranegara kaya pemilik modal bertindak sebagai negara donor yang memberikan bantuan kepada negara- negara miskin lewat badan Bank Dunia, IMF atau badan-badan sejenis lainnya. Bantuan negara kaya ini sesungguhnya bukanlah bantuan yang bersifat neteral atau gratis. Tanpa disadari negara-negara penerima bantuan itu tekah terjebak dalam hutang dan bergantung sepenuhnya kepada negara pemilik modal. Indonesia menjadi salah satu negara yang terperangkap "hutang" yang entah sampai kapan dapat terlunasi. Pada masa pemerintahan Orde Baru, pemerintah berusaha membangun perekonomian dengan sistem perekonomian Pancasila, yang konon dapat menyalurkan hasil pembangunan dan ekonomi secara merata. Namun kenyataannya, sistem ekonomi Pancasila tidak jauh berbeda dengan sistem kapitalisme, di mana hasil pembangunan dan ekonomi hnya dinikmati oleh sekelompok orang yang dekat dengan penguasa. Rakyat semakin miskin dengan parktek KKN yang dijiwai oleh keserakahan, penekanan dan penghisapan manusia atas manusia lain.

Situasi perekonomian yang buruk, diperparah lagi dengan situasi politik yang tidak sehat. Masing-masing kelompok/golongan bertikai untuk memperebutkan kekuasaan. Misalnya dalam "pertarungan" politik, seringkali masyarakat kecil atau miskin dijadikan sebagai isu untuk perjuangan untuk mencapai tujuan politik. Tetapi jika semua tujuan politik itu telah tercapai, rakyat kecil dan miskin tetap terabaikan.

Dari sudut keagamaan, pertanyaan ktitisnya, apakah benar Tuhan menciptakan manusia itu menjadi manusia yang miskin dan manusia yang kaya? Apakah manusia menjadi miskin karena memang Tuhan telah menentukan takdir seseorang untuk miskin, sehingga tidak akan mungkin mengubah kemiskinan itu? Dalam Alkitab, terdapat teks-teks yang seolah-olah mendukung bahwa kemiskinan adalah takdir Tuhan atau kemiskinan dianggap sebagai kehendak Allah, misalnya: I Samuel 2: 7a; Ayub 1: 2 dan Amsal 22: 2. Jika, teksteks tersebut dibaca sesuai dengan konteksnya, maka anggapan diatas terbantahkan. Teks I Samuel 2: 7a mengatakan bahwa Allah dapat membuat orang kaya atu miskin. Kata dapat menunjuk pada kuasa Allah, dan bukan sutu derjat kesewenang-wenangan Allah. Kemiskinan bukanlah takdir apalgi kehendak Allah.

Dalam sejarah gereja, perlakukan tidak adil terhadap perempuan sudah menjadi realitas tak terbantahkan. Ajaran Bapa gereja yang terkenal yakni Agustinus, menyatakan bahwa perempuan tidak 
memiliki gambar Allah dalam dirinya dan dianggap sebagai pelku utama dalam drama pengusiran manusia dari taman Eden (Kejadian 3). ${ }^{15}$ Perempuan dan anakanak sering menjadi kelompok yang paling menderita dan miskin dalam struktur sosial yang tidak adil. Mereka menjadi korban dari kebijakan penguasa yang kasat mata, seperti penggusuran tanpa ganti rugi, tidak adanya perlindungan terhadap hak dan organ reproduksi perempuan serta diskriminasi terhadap pekerja wanita. Sekelompok perempuan yang dicatat oleh Michael Amaladoss dalam bukunya menceritakan kisah penindasan mereka sebagai berikut:

Saya menjadi sadar bahwa perempuan-perempuan mengalami tiga lapis ketertindasan- sebagai warga negara dalam suatu sistem ekonomi yang tidak adil, sebagai pekerja dan sebagai perempuan. Perempuan diperlakukan sebagai orang yang lebih rendah tingkatannya dalam masyarakat, diingkari hak-haknya untuk mengambil bagian dalam membuat dan mengambil keputusan serta untuk berkembang menjadi manusia yang penuh Kedudukan perempuan yang rendah berasal dari hubungan mereka dengan anggota-anggota keluarga yang laki-laki. Kerap kali perempuan menjadi korban perkosaan dan bentuk-bentuk ekerasan yang lain. Sebgai bgian dari kelompok yang paling terperas dan tertindas, para pekerja perempuan di industri-industri diperlakukan sebagai pekerja yang murah. Perempuan dalam industri seks, yang seringkali terkait dengan turisme dan militerisme, dipakai sebagai barang dagangan dan dipandang sebagai orang buangan sosial. Perempuan-perempuan miskin di perkotaan senantiasa hidup terancam oleh karena pengusiran/penggusuran dan diingkari hak-hak asasinya. ${ }^{16}$

\section{Upaya Membangun Hidup Menggereja dalam Konteks Kemiskinan dan Ketidakadilan}

Orang Kristen adalah orang yang telah membuat pilihan untuk mengikuti Yesus. Pilihan mengikuti Yesus harus sejalan dengan pilihan menjadi miskin. Maksudnya, keputusan mengikuti Yesus berarti menunrut sikap keberpihakan kepada orang miskin, tertindas, diperlakukan tidak adil dan lemah, sebagaimana Yesus yang selalu berbela rasa dan berpihak kepada mereka. Preferential option for the poor and the weak dijadikan orientasi dan praxis pengikut Yesus. ${ }^{17}$ Pedro Casaldaliga dan Jose Maria Vigil mengatakan bahwa sikap berbela rasa dan berpihak kepada orang miskin dan lemah adalah identitas dan spiritualitas gereja. ${ }^{18}$ Atau dengan kata lain, keterlibatan penuh kasih dalam mendahulukan orang miskindan tertindas dalam masyrakat adalah sifat dasariah dari keterpautan gereja dengan solidaritas Allah sendiri. Hal ini oleh Aloysius Pieris sebagai kemuridan/ spiritualitas kristiani, yang memiliki kekuatan teologis, yakni antagonisme yang tak terdamaikan antara Tuhan dengan kekayaan dan perjanjian yang tak terbatalkan yang antara Tuhan dengan orang miskin. $^{19}$

\section{Spiritualitas sebagai Berjuang Menjadi Miskin}

Inti pesan Injil sebagaimana terdapat dalam khotbah di bukit menunjukkan perlawanan yang tidak terdamaikan antara Tuhan dengan mammon. Ciri pengutusan Yesus ke dunia, yakni kesetiaan/ketaatan -Nya kepada Bapa dan penolakan terhadap mammon. Mammon merupakan kekuatan yang hampir-hampir yang tak terasa bekerja dalam diri manusia, naluri keserakahan yang mendorong manusia menjadi seperti orang kaya yang bodoh dalam Injil Lukas 12: 13-21. Uang adalah salah satu manifestasi mammon yang dilawan oleh Yesus. Seringkali manusia merasa bahwa dengan uang, kedamaian, prestise dan kekuasaan mudah diperoleh. Tanpa sadar manusia masuk dalam perangkap dan diperhamba oleh mammon.

Pengikut Yesus tidak boleh tunduk dan menjadi hamba mammon. Spiritualitas berjuang menjadi miskin berarti bahwa penolakan yang sungguh-sungguh terhadap semua bentuk wajah mammon. Spiritualitas berjuang menjadi miskin adalah etos "peristiwa Yesus", baik pada saat pencobaan-Nya di padang gurun maupun dan penyaliban-Nya sebagai bentuk solidaritas.

\section{Spiritualitas sebagai Perjuangan bagi Orang Miskin}

Perjuangan menjadi miskin membawa implikasi perjuangan/pelayanan bagi orang miskin. Siprtulitas kristiani ini didasarkan pada motif mengikuti Yesus yang dulu miskin dan melayani Kristus yang pada saat ini

\footnotetext{
Rosmery Reuther. 2000. Theologizing from the Side or the Other: Women, Black, Indians and Jews. England: Sheffield Academis Press Ltd, h. 66-67.

Michael Amalados. 2001. Teologi Pembebasan Asia. Yogyakarta: Pustaka Pelajar, h. 62

Singgih, op.cit., h. 214

Maria Jose-Pedro Casaldaliga Vigil. 1994. The Spirituality of Liberation. Great Britain: BURNS \& OATES, 1994, h.137-174.

Aloysius Pieris. 1996. Berteologi dalam Konteks Asia. Yogyakarta: Kanisius. 39.
} 
ada dalam orang-orang miskin. Pertentangan Tuhan dengan mammon dan perjanjian Tuhan dengan orang miskin berarti pemihakan dan pelayanan Tuhan terhadap orang miskin, tertindas dan menderita. Pembaptisan Yesus di sungai Yordan memperlihatkan sikap kenabian Yesus, bahwa Yesus mengidentifikasi diri dengan orang miskin. Namun pembaptisan Yordan hanyalah permulaan Kalvari yang membawa Yesus kepada pengosongan diri-Nya di salib dalam kemiskinan yang menyedihkan.

Pengutusan Yesus merupakan suatu misi kenabian, yaitu pengutusan dari dan untuk orang miskin. Kristus berjuang bagi orang mskin sebagai perjuangan yang dilakukan Allah melawn orang sombong, penguasa dan orang kaya (bnd. Luk. 1:51 - 53). Antara Allah dan mammon tidak ada kompromi. "Kemiskinan" Yesus bukan hanya suatu penolakan terhadap nilai-nilai negatif mammon, serta bukan sekedar solidaritas pasif dengan orang miskin. "Kemiskinan" Yesus dipandang sebagai strtegi menentang mammon yang dinyatakan-Nya sebagai lawan Allah. Penghakiman terkahir dalam Matius 22, memperlihatkan bahwa perjuangan dan tindakan untuk orang-orang miskin adalah praxis yang dituntut oleh Allah.

Dalam rangka penyelamatan manusia, Allah melaksanakan "skenario" itu melalui Mesias yang menderita. Yesus Kristus adalah Mesias yang menderita. Terhadap hal ini, Choan Seng Song menjelaskan bahwa mesias yang mengalami penderitaanlah yang dapat menjanjikan suatu masa depan baru dan memberikan suatu kehidupan baru melalui salib dan kebangkitan-Nya. Kenosis atau pengosongan diri dalam peristtiwa salib merupakan wujud ungkapn peduli, solidaritas dan kasih Allah kepada manusia. M. M. Thomas, teolog India,yang pendapatnya dikutip oleh Yewangoe menyebutkan, salib merupakan dinamika sentral dari seluruh sejaran dan inti iman, karena tanpa salib keselamatan manusia tidak akan pernah menjadi kenyataan. ${ }^{20}$ Peristiwa salib merupakan pengampunan dosa atas semua perilaku dosa manusia. Nilai keadilan dari KerajaanAllah juga dinyatakan lewat salib, karena melalui peristiwa salib terjadi kerangka bagi semua perjuangan untuk menciptakan keadilan.

Berdasarkan spiritualitas sebagai berjuang menjadi miskin dan sebagai perjuangan bagi orang miskin mengharuskan gereja melakukan otokritik terhadap kehadiran dan pelayanannya. Sebagai komunitas iman kepada Yesus, gereja perlu menunjukkan keberpihakan kepada orang miskin, tertindas dan lemah. Salah satu bentuk pelayanan gereja adalah diakonia. Banyak gereja masih melakukan diakonia yang bersifat karitatif. E. G. Singgih melihat bahwa jika hidup menggereja sungguhsungguh berpedoman pada siritualitas Yesus, maka bentuk pelayanan diakonia gereja harus bersifat reformatif dan transformatif ${ }^{21}$ Cara hidup menggereja, gereja-gereja saat ini lebih mempertontonkan penampilan lahiriah dan demonstratif. Misalnya gedung-gedung gereja yang megah dan pakaian jabatan yang mewah, sebenarnya mengindikasikan bahwa pelayanan dan solidaritas terhadap orang yang miskin dan tertindas hanyalah dalam bentuk kata-kata.

Apapun kondisinya, orang percaya sebagai pengikut Kristus, dipanggil untuk penduli terhadap penderitaan orang laia Terhadap sikap peduli dan solider terhadap sesame, maka pertanyaan yang diajukan ialah; "apakah pelayanan itu hanya ditujukan bagi orang yang sekelompok atau segolongan?" Dalam perumpamaan orang Samaria yang baik hati, Yesus memberikan penekenan bahwa kepdulian dan pertolongan itu diberikanmelampaui batas-batas golongan, bangsa dan agama. Pengikut Yesus harus menganggap semua orang adalah sesamanya, termasuk orang miskin dan teringkir secara sosial. Justru gereja harus menunjukkan kepedulian dan keberpihakannya kepada mereka yang miskin dan menderita.

Dengan spiritualitas Yesus, gereja dalam pelayanannya harus solider dengan orang miskin dan tertindas. Solidaritas berarti keterlibatan orang percaya atau gereja dalam ikut merasakan dan menanggung kemiskinan dan penderitaan yang dialami oleh umat manusia. Pelayanan dan solidaritas gereja sungguhsungguh otentik apabila gereja rela menjadi "miskin", seperti Kristus yang telah memiskinkan diri-Nya dan mengambil rupa seorang hamba. Gereja yang dimaksud adalah gereja yang berbela rasa dan berpraxis bagi orang miskin dan lemah. Perjuangan Gereja tidak lain ialah agar manusia memiliki nilai "kemanusiaannya" sebagai manusia yang diciptakan serupa dengan gambar Allah (imago Dei).

\section{PENUTUP}

Berteologi maupun membangun hidup menggereja dalam konteks kemiskinan, penderitaan dan ketidakadilan bukanlah seseatu yang mudah dilakukan.

Yewangoe, op.cit, h. 105

Singgih, op.cit., h. 215 
memiliki gambar Allah dalam dirinya dan dianggap sebagai pelku utama dalam drama pengusiran manusia dari taman Eden (Kejadian 3). ${ }^{15}$ Perempuan dan anakanak sering menjadi kelompok yang paling menderita dan miskin dalam struktur sosial yang tidak adil. Mereka menjadi korban dari kebijakan penguasa yang kasat mata, seperti penggusuran tanpa ganti rugi, tidak adanya perlindungan terhadap hak dan organ reproduksi perempuan serta diskriminasi terhadap pekerja wanita. Sekelompok perempuan yang dicatat oleh Michael Amaladoss dalam bukunya menceritakan kisah penindasan mereka sebagai berikut:

Saya menjadi sadar bahwa perempuan-perempuan mengalami tiga lapis ketertindasan- sebagai warga negara dalam suatu sistem ekonomi yang tidak adil, sebagai pekerja dan sebagai perempuan. Perempuan diperlakukan sebagai orang yang lebih rendah tingkatannya dalam masyarakat, diingkari hak-haknya untuk mengambil bagian dalam membuat dan mengambil keputusan serta untuk berkembang menjadi manusia yang penuh. Kedudukan perempuan yang rendah berasal dari hubungan mereka dengan anggota-anggota keluarga yang laki-laki. Kerap kali perempuan menjadi korban perkosaan dan bentuk-bentuk ekerasan yang lain. Sebgai bgian dari kelompok yang paling terperas dan tertindas, para pekerja perempuan di industri-industri diperlakukan sebagai pekerja yang murah. Perempuan dalam industri seks, yang seringkali terkait dengan turisme dan militerisme, dipakai sebagai barang dagangan dan dipandang sebagai orang buangan sosial. Perempuan-perempuan miskin di perkotaan senantiasa hidup terancam oleh karena pengusiran/penggusuran dan diingkari hak-hak asasinya. ${ }^{16}$

\section{Upaya Membangun Hidup Menggereja dalam Konteks Kemiskinan dan Ketidakadilan}

Orang Kristen adalah orang yang telah membuat pilihan untuk mengikuti Yesus. Pilihan mengikuti Yesus harus sejalan dengan pilihan menjadi miskin. Maksudnya, keputusan mengikuti Yesus berarti menuntut sikap keberpihakan kepada orang miskin, tertindas, diperlakukan tidak adil dan lemah, sebagaimana Yesus yang selalu berbela rasa dan berpihak kepada mereka. Preferential option for the poor and the weak dijadikan orientasi dan praxis pengikut Yesus. ${ }^{17}$ Pedro Casaldaliga dan Jose Maria Vigil mengatakan bahwa sikap berbela rasa dan berpihak kepada orang miskin dan lemah adalah identitas dan spiritualitas gereja. ${ }^{18}$ Atau dengan kata lain, keterlibatan penuh kasih dalam mendahulukan orang miskindan tertindas dalam masyrakat adalah sifat dasariah dari keterpautan gereja dengan solidaritas Allah sendiri. Hal ini oleh Aloysius Pieris sebagai kemuridan/ spiritualitas kristiani, yang memiliki kekuatan teologis, yakni antagonisme yang tak terdamaikan antara Tuhan dengan kekayaan dan perjanjian yang tak terbatalkan yang antara Tuhan dengan orang miskin. $^{19}$

\section{Spiritualitas sebagai Berjuang Menjadi Miskin}

Inti pesan Injil sebagaimana terdapat dalam khotbah di bukit menunjukkan perlawanan yang tidak terdamaikan antara Tuhan dengan mammon. Ciri pengutusan Yesus ke dunia, yakni kesetiaan/ketaatan -Nya kepada Bapa dan penolakan terhadap mammon. Mammon merupakan kekuatan yang hampir-hampir yang tak terasa bekerja dalam diri manusia, naluri keserakahan yang mendorong manusia menjadi seperti orang kaya yang bodoh dalam Inj il Lukas 12: 13-21. Uang adalah salah satu manifestasi mammon yang dilawan oleh Yesus. Seringkali manusia merasa bahwa dengan uang, kedamaian, prestise dan kekuasaan mudah diperoleh. Tanpa sadar manusia masuk dalam perangkap dan diperhamba oleh mammon.

Pengikut Yesus tidak boleh tunduk dan menjadi hamba mammon. Spiritualitas berjuang menjadi miskin berarti bahwa penolakan yang sungguh-sungguh terhadap semua bentuk wajah mammon. Spiritualitas berjuang menjadi miskin adalah etos "peristiwa Yesus", baik pada saat pencobaan-Nya di padang gurun maupun dan penyaliban-Nya sebagai bentuk solidaritas.

\section{Spiritualitas sebagai Perjuangan bagi Orang Miskin}

Perjuangan menjadi miskin membawa implikasi perjuangan/pelayanan bagi orang miskin. Siprtulitas kristiani ini didasarkan pada motif mengikuti Yesus yang dulu miskin dan melayani Kristus yang pada saat ini

\footnotetext{
"Rosmery Reuther. 2000. neologizing from the Side or the Other: Women, Black, Indians and Jews. England: Sheffield Academis Press Ltd, h. 66-67. 
ada dalam orang-orang miskin. Pertentangan Tuhan dengan mammon dan perjanjian Tuhan dengan orang miskin berarti pemihakan dan pelayanan Tuhan terhadap orang miskin, tertindas dan menderita. Pembaptisan Yesus di sungai Yordan memperlihatkan sikap kenabian Yesus, bahwa Yesus mengidentifikasi diri dengan orang miskin. Namun pembaptisan Yordan hanyalah permulaan Kalvari yang membawa Yesus kepada pengosongan diri-Nya di salib dalam kemiskinan yang menyedihkan.

Pengutusan Yesus merupakan suatu misi kenabian, yaitu pengutusan dari dan untuk orang miskin. Kristus berjuang bagi orang mskin sebagai perjuangan yang dilakukan Allah melawn orang sombong, penguasa dan orang kaya (bnd. Luk. 1:51-53). Antara Allah dan mammon tidak ada kompromi. "Kemiskinan" Yesus bukan hanya suatu penolakan terhadap nilai-nilai negatif mammon, serta bukan sekedar solidaritas pasif dengan orang miskin. "Kemiskinan" Yesus dipandang sebagai strtegi menentang mammon yang dinyatakan-Nya sebagai lawan Allah. Penghakiman terkahir dalam Matius 22, memperlihatkan bahwa perjuangan dan tindakan untuk orang-orang miskin adalah praxis yang dituntut oleh Allah.

Dalam rangka penyelamatan manusia, Allah melaksanakan "skenario" itu melalui Mesias yang menderita. Yesus Kristus adalah Mesias yang menderita. Terhadap hal ini, Choan Seng Song menjelaskan bahwa mesias yang mengalami penderitaanlah yang dapat menjanjikan suatu masa depan baru dan memberikan suatu kehidupan baru melalui salib dan kebangkitan-Nya. Kenosis atau pengosongan diri dalam peristtiwa salib merupakan wujud ungkapn peduli, solidaritas dan kasih Allah kepada manusia. M. M. Thomas, teolog India,yang pendapatnya dikutip oleh Yewangoe menyebutkan, salib merupakan dinamika sentral dari seluruh sejaran dan inti iman, karena tanpa salib keselamatan manusia tidak akan pernah menjadi kenyataan. ${ }^{20}$ Peristiwa salib merupakan pengampunan dosa atas semua perilaku dosa manusia. Nilai keadilan dari Kerajaan Allah juga dinyatakan lewat salib, karena melalui peristiwa salib terjadi kerangka bagi semua perjuangan untuk menciptakan keadilan.

Berdasarkan spiritualitas sebagai berjuang menjadi miskin dan sebagai perjuangan bagi orang miskin mengharuskan gereja melakukan otokritik terhadap kehadiran dan pelayanannya. Sebagai komunitas iman kepada Yesus, gereja perlu menunjukkan keberpihakan kepada orang miskin, tertindas dan lemah. Salah satu bentuk pelayanan gereja adalah diakonia. Banyak gereja masih melakukan diakonia yang bersifat karitatif. E. G. Singgih melihat bahwa jika hidup menggereja sungguhsungguh berpedoman pada siritualitas Yesus, maka bentuk pelayanan diakonia gereja harus bersifat reformatif dan transformatif." Cara hidup menggereja, gereja-gereja saat ini lebih mempertontonkan penampilan lahiriah dan demonstratif. Misalnya gedung-gedung gereja yang megah dan pakaian jabatan yang mewah, sebenarnya mengindikasikan bahwa pelayanan dan solidaritas terhadap orang yang miskin dan tertindas hanyalah dalam bentuk kata-kata.

Apapun kondisinya, orang percaya sebagai pengikut Kristus, dipanggil untuk penduli terhadap penderitaan orang lain. Terhadap sikap peduli dan solider terhadap sesame, maka pertanyaan yang diajukan ialah; "apakah pelayanan itu hanya ditujukan bagi orang yang sekelompok atau segolongan?" Dalam perumpamaan orang Samaria yang baik hati, Yesus memberikan penekenan bahwa kepdulian dan pertolongan itu diberikan melampaui batas-batas golongan, bangsa dan agama. Pengikut Yesus harus menganggap semua orang adalah sesamanya, termasuk orang miskin dan teringkir secara sosial. Justru gereja harus menunjukkan kepedulian dan keberpihakannya kepada mereka yang miskin dan menderita.

Dengan spiritualitas Yesus, gereja dalam pelayanannya harus solider dengan orang miskin dan tertindas. Solidaritas berarti keterlibatan orang percaya atau gereja dalam ikut merasakan dan menanggung kemiskinan dan penderitaan yang dialami oleh umat manusia. Pelayanan dan solidaritas gereja sungguhsungguh otentik apabila gereja rela menjadi "miskin", seperti Kristus yang telah memiskinkan diri-Nya dan mengambil rupa seorang hamba. Gereja yang dimaksud adalah gereja yang berbela rasa dan berpraxis bagi orang miskin dan lemah. Perjuangan Gereja tidak lain ialah agar manusia memiliki nilai "kemanusiaannya" sebagai manusia yang diciptakan serupa dengan gambar Allah (imago Dei).

\section{PENUTUP}

Berteologj maupun membangun hidup menggereja dalam konteks kemiskinan, penderitaan dan ketidakadilan bukanlah seseatu yang mudah dilakukan.
Yewangoe, op.cit, h. 105
Singgih, op.cit., h. 215 
Tidak semua orang percaya atau gereja mampu melibatkan diri dalam bentuk yang paling sulit dan berat ini. Tetapi itu tidak berarti bahwa gereja tidak berusaha untuk memperjuangkan keadilan dan memberantas kemiskinan.

Spritualitas Yesus sebagai perjuangan menjadi miskin dan berjuang bagi orang miskin menjadi kunci reflektif dan arah praxis gereja. Kesetiaan untuk mengikuti Yesus, mensyaratkan bahwa gereja atau orang percaya berada di garda terdepan untuk memperjuangkan nilai-nilai kemanusiaan yang telah tercabik karena kuasa mammon dalam wajah kemiskinan dan ketidakdilan.

\section{Ucapan Terima Kasih}

Kami ucapakan terima kasih kepada Balai Penelitian dan Pengembangan Agama Makassar, khususnya kepada pengelolah Jurnal Al-Qalam yang telah memuat tulisan ini, semoga dapa dapat bermannfaat bagi kita semua.

\section{DAFTAR PUSTAKA}

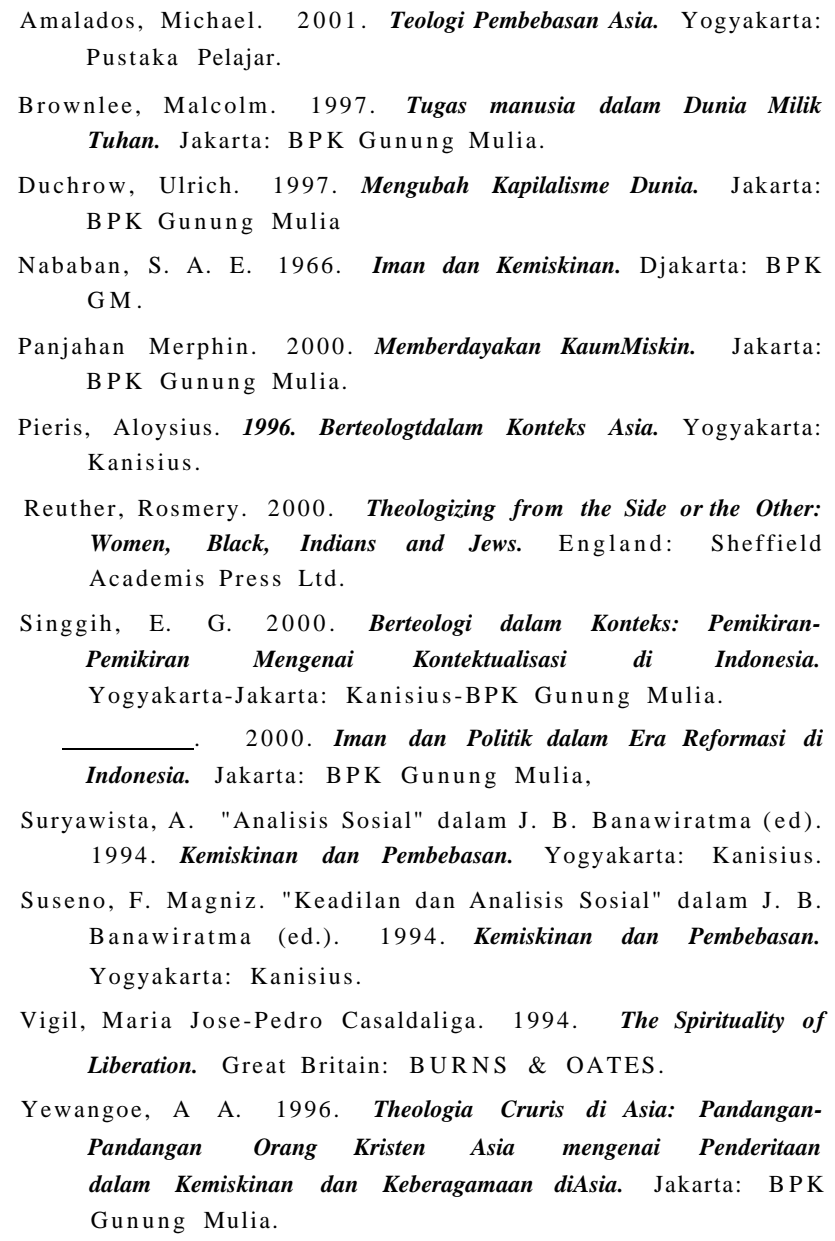

